\title{
Catestatin, an endogenous Chromogranin A-derived peptide, inhibits in vitro growth of Plasmodium falciparum
}

\author{
Aziza Akaddar • Cécile Doderer-Lang • Melissa R. Marzahn • François Delalande • \\ Marc Mousli - Karen Helle - Alain Van Dorsselaer • Dominique Aunis · Ben M. Dunn • \\ Marie-Hélène Metz-Boutigue $\cdot$ Ermanno Candolfi
}

Received: 18 September 2009/Revised: 3 December 2009/Accepted: 11 December 2009/Published online: 31 December 2009

(C) The Author(s) 2009. This article is published with open access at Springerlink.com

\begin{abstract}
Catestatin, an endogenous peptide derived from bovine chromogranin A, and its active domain cateslytin display powerful antimicrobial activities. We have tested the activities of catestatin and other related peptides on the growth of Plasmodium falciparum in vitro. Catestatin inhibits growth of the chloroquine-sensitive strain of
\end{abstract}

M.-H. Metz-Boutigue and E. Candolfi contributed equally to this work.

Electronic supplementary material The online version of this article (doi:10.1007/s00018-009-0235-8) contains supplementary material, which is available to authorized users.

A. Akaddar · C. Doderer-Lang - M. Mousli · E. Candolfi ( $₫)$ Institut de Parasitologie et de Pathologie Tropicale,

Université de Strasbourg, EA 4438, 67000 Strasbourg, France

e-mail: candolfi@unistra.fr

M. R. Marzahn · B. M. Dunn

Department of Biochemistry and Molecular Biology,

University of Florida College of Medicine,

100245 Gainesville, FL, USA

\section{F. Delalande}

Développement et Physiopathologie de l'Intestin et du Pancréas, Université de Strasbourg, INSERM U682,

67200 Strasbourg, France

K. Helle

Department of Biomedicine, University of Bergen,

Bergen, Norway

A. Van Dorsselaer

Laboratoire de spectrométrie de masse BioOrganique,

IPHC-DSA, UDS, CNRS, UMR178, 67087 Strasbourg, France

D. Aunis - M.-H. Metz-Boutigue

Physiopathologie du Système Nerveux,

Université de Strasbourg, INSERM U575,

67084 Strasbourg, France
P. falciparum 3D7, exhibiting $88 \%$ inhibition at $20 \mu \mathrm{M}$. A similar partial inhibition of parasite growth was observed for the chloroquine-resistant strain, 7G8 $(64 \%$,) and the multidrug-resistant strain, W2 (62\%). In the presence of parasite-specific lactate dehydrogenase, a specific proteinprotein interaction between catestatin and plasmepsin II precursor was demonstrated. In addition, catestatin partially inhibited the parasite-specific proteases plasmepsin in vitro. A specific interaction between catestatin and plasmepsins II and IV from P. falciparum and plasmepsin IV from the three remaining species of Plasmodium known to infect man was observed, suggesting a catestatininduced reduction in availability of nutrients for protein synthesis in the parasite.

Keywords Plasmodium falciparum · Antimicrobial peptide - Catestatin · Cateslytin . Chromogranin A · Plasmepsins II and IV

\section{Introduction}

A series of antimicrobial peptides were derived from the processing of the adrenomedullary chromogranins $\mathrm{A}$ and $\mathrm{B}$ $(\mathrm{CgA}$ and $\mathrm{CgB})$, proenkephalin- $\mathrm{A}$, and ubiquitin, all co-stored and co-secreted with catecholamines upon stimulation of the chromaffin cells [1-7]. Eight pairs of dibasic residues in bovine $\mathrm{CgA}$ correspond to major sites for processing in the intragranular matrix [8] to generate several bioactive peptides [9], among them a 21-residue-long cationic peptide (net charge +5 ) named catestatin (bovine CgA344-364, bCts). This peptide was initially characterized for its inhibitory effect on catecholamine secretion from chromaffin cells of the adrenal medulla $[10,11]$, and was identified as a product from stimulated chromaffin 
cells [12]. The sequence of Cts is highly conserved in mammals (Table 1) [13-19], and cateslytin (bovine CgA344-358, CTL) corresponds to the antimicrobial active domain [2]. The antibacterial potency of the CTL domain has been confirmed in studies of Cts as an antibacterial agent in human skin [20]. A role for these antimicrobial $\mathrm{CgA}$ peptides in innate immunity was demonstrated by their presence in secretions of stimulated polymorphonuclear neutrophils (PMNs) [2] and by the fact that Cts activates neutrophils by inducing calcium entry [21].

Malaria is endemic in about 100 developing countries and over 3 billion people live under the threat of malaria infection. Malaria causes over 1 million deaths each year, most of whom are children $[22,23]$. The most recent estimates indicate that there are more than 500 million clinical cases of malaria annually on the planet, a number that nearly doubles previous estimates [24, 25], and the disability adjusted life years (DALYs) of malaria are estimated at 45 million [23]. Furthermore, drug resistance of $P$. falciparum has emerged in all classes of antimalarial drugs [26, 27], and increased efforts in antimalarial drug discovery are urgently needed [28, 29]. Because some antiplasmodial agents are host cytotoxic molecules [30], natural non-toxic peptides might represent a new approach for malaria drug research.

Plasmepsins are aspartic proteases involved in the degradation of the host cell haemoglobin, providing nutrients for parasite growth [31] and other as yet unidentified functions. Novel and potent inhibitors of Plasmodium plasmepsins were identified by using an automated procedure to post-process the results of a large docking screen of commercially available compounds. Efforts to design new inhibitors against malarial plasmepsins have employed a range of computational tools in the design process, including homology modeling, automated docking, enzyme reaction simulations, and microscopic calculations of binding free energies [32]. Malaria parasites, both in culture and in animal models, are killed by inhibitors of plasmepsins, establishing proof of concept that these proteases are important as drug targets [33], especially when combined with the inhibition of falcipains that are also involved in haemoglobin degradation [32]. Previous studies have indicated that several peptidomimetics inhibitors, obtained from combinatorial chemistry based peptides libraries, have a high inhibitory effect on various plasmepsins [34]. Because some of these inhibitors show sequence similarities with Cts, we investigated the effect of Cts on Plasmodium growth.

The aim of the present study was to probe Cts and CTL for their antimalarial activities. Our results show that $\mathrm{Cts}$ inhibits growth of several strains of $P$. falciparum, not only the chloroquine-sensitive strain 3D7 but also the chloroquine-resistant (7G8) and the multidrug-resistant (W2) strains. The structural parameters crucial for the antimalarial potency have been identified, as well as a potential plasmodial target protein within the plasmepsin family [35].

\section{Materials and methods}

\section{Synthetic peptides}

The synthetic peptides were prepared with an Applied Biosystems 433 A synthesizer (Foster City, USA), using the stepwise solid-phase method with 9-fluoromethoxycarbonyl (Fmoc chemistry) [2, 36]. As a negative control, we used the inactive scrambled Cts breaking the putative secondary structure (SLPRRQLPSSAGMRGGKFAYF). For fluorescence studies, rhodaminated peptides were obtained as previously reported [6]. Synthetic peptides were finally purified by HPLC on C18 reverse-phase
Table 1 Alignment of Cts from different species and sequence similarity $(\%)$
Homolog residues are in white letter by comparison with human Cts

$h$ human, $b$ bovine, $m$ mouse, $r$ rat, $e$ equine, $p$ pig, $f$ frog, - deletion

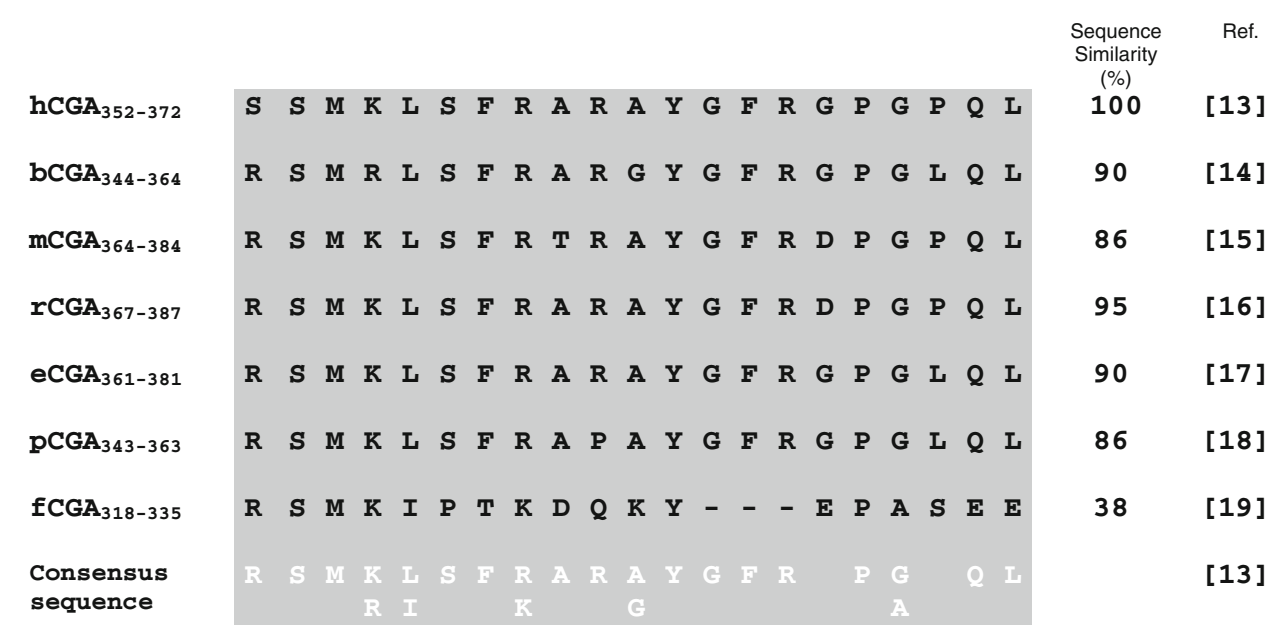

[14]

[15]

[16]

17]

18]

19]

13] 
columns and lyophylized. Purity of the synthetic peptides $(>98 \%)$ was established by HPLC and MALDI-TOF mass spectrometry, and the concentration was evaluated by automatic Edman sequencing [2] after correction with the Edman degradation yield.

Study of peptide activity on $P$. falciparum strains in vitro

We have used three $P$. falciparum strains with different origin and chemo-sensitivities: an African strain sensitive to chloroquine (3D7), a Brazilian strain resistant to chloroquine (7G8), and a South-East Asian strain resistant to chloroquine, quinine, and halofantrine (W2), kindly provided by Prof. S. Picot (EA 3732 Parasitologie, Mycologie Médicale et Pathologie Exotique, Faculté de Médecine, Université Claude Bernard, Lyon, France) and Prof. J. Le Bras (EA 209 Centre National de Référence pour la Chimiosensibilité du Paludisme, APHP, Hôpital Bichat-Claude Bernard, Paris, France). The parasite strains were kept in continuous culture with $\mathrm{O}^{+}$erythrocytes (Etablissement Français du Sang, Strasbourg, France) in a malaria culture medium (MCM, pH 7.4) consisting of RPMI 1640 supplemented with $2 \mathrm{mM}$ L-glutamine, $10 \mathrm{mM}$ Hepes (Gibco, Invitrogen, Cergy Pontoise, France), $1 \mu \mathrm{g} / \mathrm{ml}$ hypoxanthine, $\quad 0.11 \mathrm{mg} / \mathrm{ml} \mathrm{Na}$ pyruvate, and $0.02 \mathrm{mg} / \mathrm{ml}$ gentamycin in the presence of $10 \%(\mathrm{v} / \mathrm{v})$ alpha calf serum (Perbio Science, Brebières, France) for the 3D7 strain or $10 \%(\mathrm{v} / \mathrm{v})$ human group $\mathrm{A}^{+} \mathrm{B}^{+}$serum (Etablissement Français du Sang, Strasbourg, France) for the 7G8 or W2 strain, using an adapted candle jar method as previously described [37-39]. The cultures were evaluated at $1 \%$ haematocrit and $1 \%$ parasitemia. Ring-form stages and schizonts of $P$. falciparum [40] were also examined. Stock solution of aqueous peptides $(1 \mathrm{mM})$ were prepared and diluted to give final concentrations of $0.02-20 \mu \mathrm{M}$ in MCM. Antiparasitic activity was assessed at 24, 48, 72, and $96 \mathrm{~h}$ of incubation. Scrambled Cts were used as negative controls. In preliminary experiments, scrambled Cts was found to be inactive against the chloroquine-sensitive strain 3D7 (data not shown).

Estimation of peptide effects on the parasite infection rate

In order to estimate peptide effects on Plasmodium infection rate, the Plasmodium cultures were enriched with aged forms (late trophozoites and schizonts) using Plasmion (Laboratoires Fresenius Kabi, France), as previously described [40]. Thereafter, young forms of Plasmodium (ring stages) were counted after $24 \mathrm{~h}$ of incubation in the presence of $50 \mu \mathrm{M} \mathrm{Cts}$ at $37^{\circ} \mathrm{C}$. Control experiments were performed with scrambled $\mathrm{Cts}$ at the same conditions. In all experiments, parasitemia was determined by light microscope $(\times 100)$, counting the proportion of parasitized red blood cells (RBCs) in about 20 fields of thin blood films prepared from culture. Mean and standard deviation were calculated from three different experiments, each being evaluated by three different readers [28]. In parallel, Plasmodium-derived lactate dehydrogenase (pLDH), a parasite-specific intracellular metabolic enzyme, was measured in whole blood in the absence or presence of peptides, using a commercial ELISA kit (DiaMed ELISA Malaria Antigen test; Cressier sur Morat, Switzerland) according to the manufacturer's recommendations [41]. Each peptide was incubated in MCM at $20 \mu \mathrm{M}$ for $48 \mathrm{~h}$ before analysis by pLDH-ELISA. The pLDH test was used to determine the $50 \%$ inhibitory concentration $\left(\mathrm{IC}_{50}\right)$. The $\mathrm{IC}_{50}$ was estimated by linear regression analysis (standard curve) [ICEstimator software (http://www.antimalarialicestimator.net/)]. For each peptide or drug, the data from the ELISA assay correspond to ten different concentrations. For each concentration, the mean of triplicate measurements was obtained and expressed in percent of the enzyme activity obtained with the controls (100\%).

Analysis of Cts stability in the culture medium by reverse phase HPLC

Cts was incubated in MCM at $20 \mu \mathrm{M}$ for $30 \mathrm{~min}$ to $24 \mathrm{~h}$ before analysis by RP-HPLC. The MCM medium and an aqueous solution of $20 \mu \mathrm{M}$ Cts were used as separate controls. The analyses were performed on a MachereyNagel Nucleosil 300-5C18 column $(4 \times 250 \mathrm{~mm})$ (Hoerdt, France) with the Akta Purifier HPLC system (Amersham Biosciences, Les Ulis, France). The solvent system consisted of $0.1 \%(\mathrm{v} / \mathrm{v})$ trifluoroacetic acid in water (solvent $\mathrm{A}$ ) and $0.09 \%(\mathrm{v} / \mathrm{v})$ trifluoroacetic acid in $70 \%$ acetonitrile (Carlo Erba, Rodano, Italy) in water (solvent B). Elutions were performed at a flow rate of $700 \mu \mathrm{L} / \mathrm{min}$ using the gradient \% B (0-10) for the first $10 \mathrm{~min}$ and then \% B (10100) for the remaining $40 \mathrm{~min}$. Peptide absorbance in the eluate was monitored at $214 \mathrm{~nm}$.

Haemolytic activity assay

Normal RBCs were washed three times in sterile PBS. After each wash, the tube was centrifuged at $450 \mathrm{~g}$ for $5 \mathrm{~min}$ at $4^{\circ} \mathrm{C}$, and then PBS was added to reach a final haematocrit concentration of $2 \%$. Aqueous solutions of peptides were prepared by 10 serial dilutions in sterile PBS from a stock of $1 \mathrm{mM}$. Diluted peptides $(0-300 \mu \mathrm{M}$, $150 \mu \mathrm{L}$ ) were added to suspend RBCs in each of 96 wells in a microplate. The haemolytic assay was carried out in triplicate, using 5\% SDS as a positive control $(100 \%$ haemolysis). The plate was incubated with agitation at 
$37^{\circ} \mathrm{C}$ for $40 \mathrm{~min}$, centrifuged at $400 \mathrm{~g}$ during $5 \mathrm{~min}$ at $4^{\circ} \mathrm{C}$, followed by aspiration of supernatant and finally measuring the absorbance at $438 \mathrm{~nm}$. Haemolysis of each concentration was calculated as a percentage by dividing the optical density (OD) for each concentration by the OD for $5 \%$ SDS.

\section{Interactions between Cts and Plasmodium proteins}

Plasmodium cultures were enriched with infected RBCs (iRBCs) from $15 \%$ in the initial cultures to $80 \%$ following Plasmagel treatment (Plasmion; Fresenius Kabi). Lysis of iRBCs with $0.05 \%$ saponin was carried out as previously described [42]. The solubilized Plasmodium was centrifuged for $5 \mathrm{~min}$ at 4,000 $\mathrm{g}$ and washed three times in PBS. The pellet was sonicated $(4 \times 10 \mathrm{~s})$, centrifuged twice at $4,000 \mathrm{~g}$, and the second supernatant was kept for further use. The two pellets were incubated with $0.05 \%$ Nonidet P-40 (Sigma-Aldrich, St-Quentin, France) and sonicated. The two resulting supernatants were pooled to constitute the Plasmodium soluble extract (PSE). The protein content was measured by Bradford assay (Bio-Rad, Marnesla-Coquette, France). PSE was separated on SDS-10\% PAGE under reducing conditions (in Bio-Rad apparatus). After transfer to a PVDF membrane (Bio-Rad), the protein bands were immunodetected using anti-MSP1 Mab (PEM-2; Santa-Cruz Biotechnology, Heidelberg, Germany) and a hyper-immune sera resulting from the pool of several African residents infected by $P$. falciparum, and containing high levels of malaria antibodies measured by a specific ELISA [43]. The secondary antibody was either an anti-human IgG (Roche Diagnostics, Meylan, France) or an anti-mouse IgG (Sigma, St Louis, MO, USA) conjugated to peroxydase, and the complex of antibodies and protein was visualized by ECL-autoradiography (Pierce ECL Western Blotting Substrate; Fisher Bioblock, Illkirch, France). Specific interaction between PSE and Cts was determined by incubating biotin-labelled peptides $(100 \mu \mathrm{g}$ of Cts or scrambled Cts) with $100 \mu \mathrm{L}$ of streptavidinconjugated Sepharose beads (GE Healthcare, Orsay, France) under constant shaking for $2 \mathrm{~h}$ at $4^{\circ} \mathrm{C}$. The beads were centrifuged at $15,000 \mathrm{~g}$ for $15 \mathrm{~min}$, and washed in PBS containing a cocktail of proteases inhibitors (Roche Diagnostics). The beads were incubated with $100 \mu \mathrm{g}$ of PSE under constant shaking overnight at $4^{\circ} \mathrm{C}$, then washed four times in PBS and centrifuged at $15,000 \mathrm{~g}$ for $15 \mathrm{~min}$. PSE proteins interacting with the biotinylated Cts were identified by boiling the beads in $30 \mu \mathrm{L}$ of Laemmli buffer and separating on $10 \%$ SDS-PAGE, under reducing conditions (Bio-Rad apparatus). Similar experiments were conducted with biotinylated scrambled Cts as controls. ${ }^{1} \mathrm{D}$ SDS-PAGE gels were prepared for mass spectrometry analysis.
In-gel digestion of separated components

Gels were systematically cut into slices and in-gel digestion was performed with an automated protein digestion system, MassPREP Station (Waters, Manchester, UK). The gel slices were washed three times in a mixture containing $25 \mathrm{mM}$ ammonium bicarbonate: acetonitrile $(1: 1, \mathrm{v} / \mathrm{v})$. The cysteine residues involved in disulfide bridges were reduced by adding $50 \mu \mathrm{L}$ of $10 \mathrm{mM}$ dithiothreitol at $57^{\circ} \mathrm{C}$ and alkylated by adding $50 \mu \mathrm{L}$ of $55 \mathrm{mM}$ iodoacetamide. After dehydration with acetonitrile, the proteins were cleaved with $40 \mu \mathrm{L}$ of modified porcine trypsin $(12.5 \mathrm{ng} / \mu \mathrm{L}$; Promega, Madison, WI, USA) in $25 \mathrm{mM}$ ammonium bicarbonate, $\mathrm{pH}$ 7.2 at $37^{\circ} \mathrm{C}$ for $4 \mathrm{~h}$. Finally, the tryptic peptides were extracted with $60 \%$ acetonitrile in $5 \%$ formic acid, followed by a second extraction with $100 \%(\mathrm{v} / \mathrm{v})$ acetonitrile.

Mass spectrometry analysis of tryptic digests

NanoLC-MS/MS analysis was performed on a nanoACQUITY Ultra-Performance-LC (UPLC; Waters) coupled to a hybrid quadrupole orthogonal acceleration time-of-flight tandem mass spectrometer (SYNAPT ${ }^{\mathrm{TM}} \mathrm{MS}$; Waters). Each sample was loaded on a $20 \times 0.18 \mathrm{~mm}, 5 \mu \mathrm{m}$ Symmetry C18 precolumn (Waters), and the peptides were separated on a ACQUITY UPLC ${ }^{\circledR}$ BEH130 C18 column (Waters) $(200 \times 0.075 \mathrm{~mm}, 1.7 \mu \mathrm{m}$ particle size $)$. The solvent system consisted of $0.1 \%$ formic acid in water (solvent A) and $0.1 \%$ formic acid in acetonitrile (solvent B). Trapping was performed for $3 \mathrm{~min}$ at $5 \mu \mathrm{L} / \mathrm{min}$ with $99 \%$ of solvent $\mathrm{A}$ and $1 \%$ of solvent B. Elution was performed at a flow rate of 400 $\mathrm{nL} / \mathrm{min}$, using 1-40\% gradient (solvent $\mathrm{B}$ ) over $35 \mathrm{~min}$ at $45^{\circ} \mathrm{C}$ followed by $65 \%$ (solvent B) over $5 \mathrm{~min}$.

The MS and MS/MS analyses were performed on the SYNAPT $^{\mathrm{TM}}$ (Waters) equipped with a Z-spray ion source in positive mode. The capillary voltage was set at $3.5 \mathrm{kV}$ and the cone voltage at $35 \mathrm{~V}$. The SYNAPT is equipped with a lock-mass system. Mass calibration of the TOF in the $50-2,000 \mathrm{~m} / \mathrm{z}$ range was achieved using phosphoric acid. In line correction of this calibration was achieved using lock-mass on product ions derived from the $\left[\mathrm{Glu}^{1}\right]$ fibrinopeptide B (GFP).

The ion $(\mathrm{M}+2 \mathrm{H})^{2+}$ at $\mathrm{m} / \mathrm{z} 785.8426$ is used to calibrate MS data and the fragment ion $(\mathrm{M}+\mathrm{H})^{+}$at $\mathrm{m} / \mathrm{z}$ 684.3469 is used to calibrate MS/MS data.

For tandem MS experiments, the system was operated with automatic switching between MS and MS/MS modes (MS $0.5 \mathrm{~s} / \mathrm{scan}$ on $\mathrm{m} / \mathrm{z}$ range $250-1,500$ and MS/MS $0.7 \mathrm{~s} / \mathrm{scan}$ on $\mathrm{m} / \mathrm{z}$ range $50-2,000$ ). The three most abundant peptides (intensity threshold 60 counts/s), preferably doubly and triply charged ions, were selected on each MS spectrum for further isolation and CID fragmentation. Fragmentation was performed using argon as the collision gas. To improve 
the quality of MS/MS spectra during NanoLC-MS/MS analysis, we empirically derived energy curves depending on the $\mathrm{m} / \mathrm{z}$ value of the selected precursor ion. For each $\mathrm{m} / \mathrm{z}$ value, two different collision energies were applied.

The complete system was fully controlled by MassLynx 4.1 (SCN 566; Waters). Raw data collected during NanoLC-MS/MS analyses were processed and converted with ProteinLynx Browser 2.3 (23; Waters) into pkl peak list format. Normal background subtraction type was used for both MS and MS/MS with a 5\% threshold and polynomial correction of Order 5 and deisotoping was performed.

Protein identification

The MS and the MS/MS data were analyzed using a local Mascot server (version MASCOT 2. 2. 0; MatrixScience, UK) and a composite target-decoy database including the protein sequences of the UniProtKB/Swiss-Prot version 55.2 and reversed versions of these sequences (total 719, 884 entries).

Searches were performed with a mass tolerance of $50 \mathrm{ppm}$ for MS mode and 0.2 Da in MS/MS mode. One missed cleavage per peptide was allowed and variable modifications were taken into account such as carbamidomethylation of cysteine and oxidation of methionine.

To minimize false positive identifications, the results were subjected to stringent filtering criteria. For the identification of a protein with two peptides or more, at least two unique peptides had to fit a Mascot ion score above 25. In the case of single peptide hits, the score of the unique peptide must be greater than 50. For estimation of the false positive rate, a target-decoy database search was performed $[44,45]$. With this approach, peptides are matched against a database consisting of the native protein sequences found in the database (target) and of the sequence-reversed entries (decoy). The evaluations were performed using the peptide validation software Scaffold (Proteome Software, Portland, USA). This strategy was used to obtain a final catalogue of proteins with an estimated false positive rate below $1 \%$.

\section{Plasmepsin kinetic assay}

Wild-type recombinant plasmepsins proenzymes (PM II and IV) were expressed and purified as previously described [46, 47]. For the kinetic assays, the enzyme was incubated in $0.1 \mathrm{M}$ sodium acetate, $\mathrm{pH} 4.5$ for $5 \mathrm{~min}$ at $37^{\circ} \mathrm{C}$ to allow autoconversion to the mature enzyme and interaction with the inhibitor. The enzyme (free or inhibitor-complexed form) was mixed with a chromogenic substrate [46] and the initial rates of cleavage were measured using a Cary 50 Bio UV-Visible spectrophotometer for at least six defined substrate concentrations and at least two different concentrations of inhibitors. Ki values were determined using SigmaPlot (Systat Software) [48].

Statistical analysis

The efficacy of the different peptide concentrations relative to the control was evaluated using the Kruskal-Wallis test. Different substrate concentrations with different rates of inhibition are presented in bar graphs and compared to the control inhibition rate, considering that parasitemia in the control bar will represent $0 \%$ inhibition. The test was performed three times to assure reproducible results. $P$ values $<0.05$ for difference from controls were considered significant. Statistical analysis was done using GraphPad Instat software (San Diego, CA, USA).

\section{Results}

Cts inhibits Plasmodium falciparum growth

Peptide activities against Plasmodium strains' growth were measured in vitro. Maximal growth inhibition of the 3D7 strain was reached with $20 \mu \mathrm{M}$ hCts (Fig. 1a). When we assayed hCts at the same concentration on two other strains, 7G8 (CQ resistant) and W2 (multidrug resistant), we reached 64 and 62\%, respectively (Fig. 1b). Similar results were observed for ring-form stages and schizonts of the same $P$. falciparum strain (data not shown). The chloroquine-resistant $P$. falciparum strain $7 \mathrm{G} 8$ strain was less sensitive to hCts with growth inhibited by $36 \%$ at $20 \mathrm{nM}$ and $64 \%$ at $20 \mu \mathrm{M}$ (Fig. 2a). Similarly, the growth of the multidrug-resistant $P$. falciparum strain $\mathrm{W} 2$ was inhibited by 22 and $62 \%$ at $20 \mathrm{nM}$ and $20 \mu \mathrm{M}$, respectively (Fig. 2b).

The production of $\mathrm{pLDH}$ persisted in these non-proliferating stage $48 \mathrm{~h}$ later, consistent with a viable state of the growth-inhibited parasite in the presence of hCts (Fig. 2a). We have estimated the half-life of hCts to $12 \mathrm{~h}$ by HPLC and Edman sequencing (data not shown). Therefore, we added successive amounts of peptide to cell cultures, but the inhibitory performance was not improved, and we did not observe any kind of haemolytic activity (data not shown). The $\mathrm{IC}_{50}$ was estimated at $14 \mu \mathrm{M}$ by $\mathrm{pLDH}$ measurement (Fig. 2b), pointing out that complete growth inhibition never exceeded $90 \%$ at any tested concentration higher than $20 \mu \mathrm{M}$ hCts.

Structure-activity relationship studies of Cts against the 3D7 strain

Human Cts was more active than the bovine peptide with respect to growth inhibitory effects on the 3D7 strain. The sequence similarity between the two Cts peptides is $90 \%$ 



Fig. 1 In vitro action of human $\mathrm{Cts}\left(\mathrm{hCGA}_{352-372}\right)$ on the growth of $P$. falciparum strains. a Parasitemia (\%) was evaluated after adding hCts $(20 \mathrm{nM}-50 \mu \mathrm{M})$ to cultured $P$. falciparum strain 3D7 during 4 days post-infection (D0-D4). Maximal growth inhibition of 3D7 strain was reached with $20 \mu \mathrm{M}$; Control corresponds to P. falciparum 3D7 strain culture with the inactive scrambled hCts $(20 \mu \mathrm{M})$. b Growth inhibition induced by $20 \mu \mathrm{M}$ of hCts on $P$. falciparum chloroquine sensible strain 3D7, chloroquine-resistant strain 7G8, and multidrug-resistant strain W2. Control corresponds to $P$. falciparum $3 \mathrm{D} 7$ strain culture with the inactive scrambled peptide $(20 \mu \mathrm{M})$. Results are expressed as mean and SD from three independent experiments and were compared to control, ${ }^{*} P<0.01$

[13-19] (Fig. 3). Four substitutions are apparent in positions $1,4,11$, and 19 of the 21 residues, resulting in a higher cationic charge $(+5)$ in bCts and bCTL than in hCts
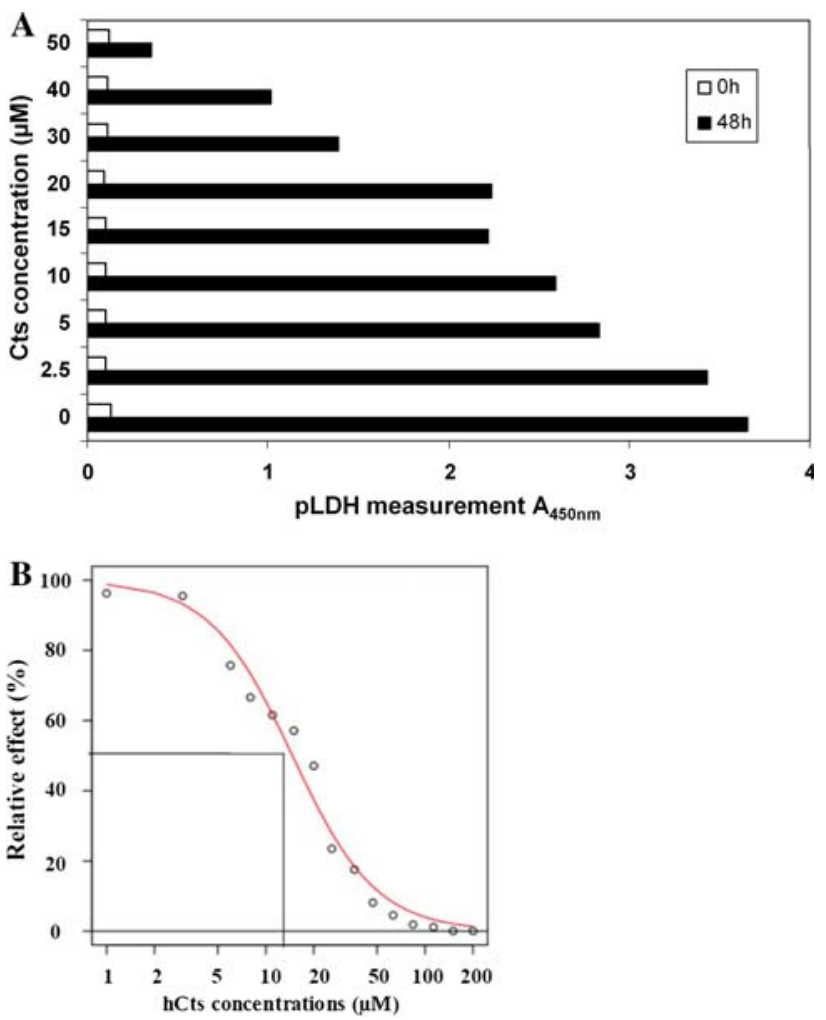

Fig. 2 a Measurement by ELISA $\left(\mathrm{A}_{450} \mathrm{~nm}\right)$ of Plasmodium lactate dehydrogenase antigen (pLDH), as a reflection of parasite growth. $P$. falciparum 3D7 strain was cultured for 0 and $48 \mathrm{~h}$ without $\mathrm{Cts}$ and with Cts $(2.5-50 \mu \mathrm{M})$. b hCts IC50 was measured on P. falciparum 3D7 strain with the ICEstimator (http://www.antimalarial-icestimator.net/)

(+4) (Fig. 3). Notably, the substitutions of the serine residue in position 1 of hCts to arginine in bCts and bCTL, and of the alanine residue in position 11 of hCts to glycine in bCts and bCTL may be important for the higher inhibitory potency of hCts. In order to identify the region of Cts crucial for the antiplasmodial activity, several truncated peptides were also compared for growth inhibition of the chloroquine-sensitive strain, 3D7 (Fig. 3). The N-terminal region (Cat 1) and the median region (Cat 3 ) from which a glycine residue in position 13 was deleted were found to be as effective as the intact bCts. In contrast, the C-terminal region (Cat 2) and the scrambled hCts were devoid of inhibitory effects, while the shortest peptide (Cat 4), comprising the highly conserved sequence LSFR, was able to inhibit parasite growth by $50 \%$ (Fig. 3). Altogether, these data demonstrate the importance of the LSFR sequence for evaluating antiplasmodial activity.

Identification of plasmodial protein targets by mass spectrometry analysis

Soluble extracts of Plasmodium cultures were incubated with biotinylated hCts (or scrambled hCts as a negative 




\begin{tabular}{|c|c|c|}
\hline PEPTIDES & Inhibition (\%) & SEQUENCES \\
\hline $\mathrm{hCGA}_{352-372}$ & 88 & SSMK $^{1} \underline{\text { LSFRARAYGFRGPGPQL }}$ \\
\hline Scrambled hCatestatin & 0.4 & SLPRRQLPSSAGMRGGKFAYF \\
\hline $\mathrm{bCGA}_{344-364}$ & 63 & RSMR $^{1}$ LSFRARGYGFRGPGLQL \\
\hline bCGA $_{344-358}$ Cateslytin & 67 & RSMR $^{1}{ }^{\text {LSFRARGYGFR }}$ \\
\hline Cat $1:$ bCGA $_{344-351}$ & 62 & $\mathrm{RSMR}^{1} \underline{\underline{\mathrm{LSFR}}}$ \\
\hline Cat $2:$ hCGA $_{360-372}$ & 1 & ARAYGFRGPGPQL \\
\hline Cat $3:$ bCGA $_{348-358}$ & 63 & ${ }^{1}$ LSFRARGY_FR \\
\hline Cat $4: \mathrm{bCGA}_{348-351}$ & 50 & ${ }^{1} \mathrm{LSFR}$ \\
\hline
\end{tabular}

Fig. 3 In vitro inhibition (\%) of the growth of P. falciparum strain 3D7 by several Cts-derived peptides at $20 \mu \mathrm{M}$ : hCts, bCts, CTL (bCGA $344-358)$, Cat 1 (bCGA $344-351)$, Cat 2 (hCGA $360-372)$, Cat 3 (bCGA ${ }_{348-358}$ with deletion of G357), Cat 4 (bCGA $348-351$ ), and scrambled hCts, Control corresponds to Plasmodium growth without peptide. Each peptide was incubated in MCM at $20 \mu \mathrm{M}$ concentration for $48 \mathrm{~h}$ before analysis by pLDH-ELISA. Results are expressed as mean and $\mathrm{SD}$ correspond to three independent experiments, $* \mathrm{p}<0.01$

control) and streptavidin-conjugated Sepharose beads overnight at $4^{\circ} \mathrm{C}$. The parasite proteins bound to the washed beads were eluted at $100^{\circ} \mathrm{C}$ and identified by mass spectrometry analysis of components separated by ${ }^{1} \mathrm{D}$ SDSPAGE. The gels were systematically cut into 46 bands and treated in-gel with trypsin. The tryptic released peptides were analyzed by nano LC-MS/MS. Three parasite proteins were specifically pulled down by Cts: tubulin beta chain (P14643), proliferating cell nuclear antigen (P31008) and a precursor of plasmepsin II (P46925) (Table 2, and electronic supplementary data: mass spectrometryproteomic analysis).

Inhibition of Plasmepsin activities by Cts

An in vitro assay was established to assess the putative inhibitory potencies of $\mathrm{Cts}$ on recombinant PfPM2 and PfPM4 (PfPM: P. falciparum plasmepsin) (Table 3). Ki values of 130-140 nM hCts were obtained for both PfPM2 and PfPM4. In contrast, the Ki values for the scrambled hCts for both enzymes were 26 and 40 fold higher, respectively, while the $\mathrm{Ki}$ values for the shortest active peptide LSFR were 14- to 15 -fold higher than for hCts.

Plasmepsin IV homologues are found in the remaining species of Plasmodium known to infect man: $P$. ovale, $P$. vivax, and $P$. malariae. When we compared the Ki values for hCts for these plasmepsins to those obtained for PfPM4 (Table 3), the order of inhibitory potency of hCts was: PfPM4 $>$ PvPM4 $\gg$ PoPM4 $\gg$ PmPM4. For all four Plasmodium species, the order of inhibitor potencies was hCts $\ggg$ LSFR $>$ scrambled hCts.

\section{Discussion}

In the present study, we have shown for the first time that hCts, the natural cationic antimicrobial CgA-derived peptide, inhibits Plasmodium growth in vitro, not only of the chemo-sensitive strain 3D7, but also of the two drugresistant strains, $7 \mathrm{G} 8$ and $\mathrm{W} 2$, of $P$. falciparum. Until $100 \mu \mathrm{M}$, CTL, the active domain, does not display lytic effect on RBCs and other host cells (human neuroblastoma SKNMC and cardiomyocytes H9C2) (Jenny Briolat, Thesis of the University of Strasbourg, 2006). The parasite remains viable as assessed by persistence of a basic pLDH production in the presence of hCts, also suggesting a role for this $\mathrm{CgA}$ peptide in the first line of defence against invasion of this pathogen, and explaining why growth inhibition was never complete. Recently, our group has demonstrated the immunomodulatory properties of Cts by stimulating neutrophils [49]. Although yet to be demonstrated during human or rodent malaria infections, Cts

Table 2 Putative targets of Cts identified by mass spectrometry

\begin{tabular}{|c|c|c|c|c|}
\hline Protein name & Accession numbers & $\begin{array}{l}\text { Protein molecular } \\
\text { weight (AMU) }\end{array}$ & $\begin{array}{l}\text { Catestatin } \\
(\%)\end{array}$ & $\begin{array}{l}\text { Scrambled } \\
\text { Catestatin }\end{array}$ \\
\hline $\begin{array}{l}\text { Tubulin beta chain: Plasmodium falciparum } \\
\text { (isolate K1/Thailand) }\end{array}$ & P14643|TBB_PLAFK,Q7KQL5|TBB_PLAF7 & $49,732.8$ & 99 & 0 \\
\hline Plasmepsin-2 precursor: Plasmodium falciparum & P46925IPLM2_PLAFA & $51,473.8$ & 99 & 0 \\
\hline $\begin{array}{l}\text { Proliferating cell nuclear antigen: Plasmodium } \\
\text { falciparum (isolate K1/Thailand) }\end{array}$ & P31008|PCNA_PLAFK,P61074|PCNA_PLAF7 & $30,570.3$ & 98 & 0 \\
\hline
\end{tabular}


Table $3 \mathrm{Ki}$ values in $\mathrm{nM}$ of catestatin, scrambled catestatin, and LSFR with plasmepsin II from P. falciparum, plasmepspin IV from all four Plasmodium species known to infect man

\begin{tabular}{llllll}
\hline Inhibitor/plasmepsin & PfPM2 & PfPM4 & PoPM4 & PvPM4 & PmPM4 \\
\hline $\mathrm{K}_{\mathrm{i}(\mathrm{nM})}$ & & & & & \\
$\quad$ Catestatin & $130 \pm 10$ & $140 \pm 10$ & $1,000 \pm 120$ & $320 \pm 30$ & $5,600 \pm 770$ \\
Scrambled Catestatin & $3,400 \pm 310$ & $5,600 \pm 780$ & $10,600 \pm 1,300$ & $2,800 \pm 270$ & $51,000 \pm 6,000$ \\
LSFR & $2,000 \pm 200$ & $1,900 \pm 190$ & $7,800 \pm 850$ & $1,400 \pm 150$ & $31,000 \pm 2,400$ \\
\hline
\end{tabular}

secretion from neuroendocrine cells and PMNs triggered by invading microorganisms [2] may also contribute to the first defence against the $P$. falciparum infection.

Antimicrobial peptides selectively targeting pathogens often present a broad spectrum of action. Several naturally occurring antimicrobial peptides have been tested as potential anti-plasmodium agents, including scorpin, magainin 2, cecropin B, defensin, and dermaseptin S3 and S4 [50-53], as well as the synthetic peptides Vida 1-3, P2WN, ILF, SM1, SB-37, Shiva-1 and 3, and LAH4 [54-59]. Hence, a discussion of the structural requirements for the Cts molecule, a peptide naturally present in humans, on parasite growth, and on the inhibitory potential of the peptide on parasite specific enzymes are important in this context. It is evident from the present experiments that the Cts domain LSFR by itself expresses a growth inhibitory potency $(50 \%$ inhibition of the 3D7 strain; Fig. 3). Intriguingly, the $\mathrm{N}$-terminal serine residue unique to hCts appeared essential for maximal inhibition (88\%) relative to the significantly lower inhibitory effects of bCts and bCTL (63-67\%), both containing arginine as a substitute for the $\mathrm{N}$-terminal serine. Moreover, the bovine peptides Cat 1 and Cat 3, both containing the LSFR-sequence, were equipotent with bCts and CTL, while the scrambled hCts and the C-terminal Cat 3 were completely inactive. These findings strongly suggest that the observed growth inhibitory potency on $P$. falciparum is specific for the primary sequence of hCts and dependent on the conservation of the LSFR domain.

Among the synthetic peptides described up to now as inhibitors of Plasmodium growth are inhibitors of plasmepsin family members. They were found after homology modeling and molecular docking [32]. Previous computational inhibitor design against malaria plasmepsin II [32] demonstrates that the natural haemoglobin peptide RMFLSF [32-38] is a substrate of the aspartic protease, which rapidly cleaves haemoglobin between F33 and L34. Interestingly, Cts sequence and LSFR both include the short LSF fragment. This observation suggests that Cts might interact with plasmepsin II as a competitive substrate. A non-specific binding of the tetrapeptide cannot be excluded despite the fact that LSFR, but not the scrambled peptide, partially arrested Plasmodium growth in vitro. The mechanism underlying this phenomenon will be a topic for future experiments. Indeed, the identification by mass spectrometry of Cts binding proteins in Plasmodium extract show the presence of tubulin beta chain, proliferating cell nuclear antigen and plasmepsin II precursor. It cannot be excluded that $\mathrm{Cts}$ might interact with parasite microtubules $[60,61]$ or proliferating cell nuclear antigen [62] (Table 2), but detection of plasmepsin II precursor attracted interest because, as detailed above, parasite-specific aspartic proteases of the plasmepsin family have a significant role in the processing of haemoglobin. PfPM1, PfPM2, and PfPM4 are localized in the digestive vacuole found in $P$. falciparum [63-65], and the present data made it evident that hCts is able to preferentially inhibit the in vitro activity of recombinant PfPM2 and PfPM4 of P. falciparum (Table 3). In previous studies [47], the quadruple-PM KO 3D7 strain showed a significantly slower rate of growth in standard medium similar to the wild-type 3D7 treated with hCts without lysis of parasites. Following these observations, we can suppose that hCts can interact with plasmepsins and inhibit their functions. The corresponding $\mathrm{Ki}$ values of 130-140 nM Cts suggest that these two PMs may be targets for this peptide in this species of Plasmodium, in addition to the sequence comparison with the natural substrate and the incomplete Plasmodium growth inhibition. In addition, Cts also showed good efficacy as a plasmepsin inhibitor on resistant as well as sensitive $P$. falciparum strains (not shown). Of interest, plasmepsin IV is shared by all four Plasmodium species known to infect man. The present experiments have shown that hCts is also able to inhibit, albeit with significantly higher Ki values, the activity of recombinant plasmepsin IV from $P$. ovale, $P$. vivax, and $P$. malariae in vitro, demonstrating some inter-strain inhibitory capacities (Table 3). Ki values for a series of synthetic inhibitors of PfPM1 and PfPM2 are available in the literature [66]. The Ki values for Cts on P. falciparum were comparable, if not better, than those reported for most synthetic inhibitors. Cts IC50 of the 3D7 strain $(14 \mu \mathrm{M})$ is high, when compared to chloroquine (IC50 $=18-38 \mathrm{nM}$ ). However, Cts and its derived peptides may be interesting for the exploration of new antimalarial drugs based upon observed plasmepsin inhibition. Future experiments to demonstrate that $\mathrm{Cts}$ is a new actor of innate immunity to fight $P$. falciparum will involve detecting the presence 
of $\mathrm{Cts}$ in human and in malaria-infected mice in acute infection and determining its role in vivo.

Acknowledgments This work was funded by Inserm (U575), Université de Strasbourg (France), CNRS, le Ministère de la Recherche et de l'Education, and supported by les Hôpitaux Universitaires de Strasbourg, the Région Alsace (MHMB). S.K.M. is supported by grants from the National Institutes of Health and the Veterans Affairs, USA. We are grateful to Bernard Guerold (Inserm U575) for peptides synthesis and we thank J.B. Dame, A.W. Pfaff, T. Abdelraman, and P.J. Weina, for their help and their scientific input for this project.

Open Access This article is distributed under the terms of the Creative Commons Attribution Noncommercial License which permits any noncommercial use, distribution, and reproduction in any medium, provided the original author(s) and source are credited.

\section{Appendix: List of Accession Numbers (Proteins)}

\section{hCgA (human Chromogranin A): P10645}

bCgA (bovine Chromogranin A): P05059

mCgA (mouse Chromogranin A): P26339

rCgA (rat Chromogranin A): P10354

eCgA (equine Chromogranin A): Q9XS63

pCgA (pig Chromogranin A): $\mathrm{P} 04404$

fCgA (frog Chromogranin A): Q9W7A0_RANRI

pLDH (plasmodium Lactate DeHydrogenase): Q27743

PfTubulin $\beta$ chain: P14643

Proliferating Cell Nuclear Antigen: P31008

PfPlasmepsin II precursor, PfPM2: P46925

\section{References}

1. Metz-Boutigue MH, Kieffer AE, Goumon Y, Aunis D (2003) Innate immunity: involvement of new neuropeptides. Trends Microbiol 11:585-592

2. Briolat J, Wu SD, Mahata SK, Gonthier B, Bagnard D, ChasserotGolaz S, Helle KB, Aunis D, Metz-Boutigue MH (2005) New antimicrobial activity for the catecholamine release-inhibitory peptide from chromogranin A. Cell Mol Life Sci 62:377-385

3. Strub JM, Garcia-Sablone P, Lonning K, Taupenot L, Hubert P, Van Dorsselaer A, Aunis D, Metz-Boutigue MH (1995) Processing of chromogranin B in bovine adrenal medulla. Identification of secretolytin, the endogenous C-terminal fragment of residues 614-626 with antibacterial activity. Eur J Biochem 229:356-368

4. Goumon Y, Strub JM, Moniatte M, Nullans G, Poteur L, Hubert P, Van Dorsselaer A, Aunis D, Metz-Boutigue MH (1996) The C-terminal bisphosphorylated proenkephalin-A-(209-237)-peptide from adrenal medullary chromaffin granules possesses antibacterial activity. Eur J Biochem 235:516-525

5. Kieffer AE, Goumon Y, Ruh O, Chasserot-Golaz S, Nullans G, Gasnier C, Aunis D, Metz-Boutigue MH (2003) The N- and C-terminal fragments of ubiquitin are important for the antimicrobial activities. FASEB J 17:776-778
6. Lugardon K, Chasserot-Golaz S, Kieffer AE, Maget-Dana R, Nullans G, Kieffer B, Aunis D, Metz-Boutigue MH (2001) Structural and biological characterization of chromofungin, the antifungal chromogranin A-(47-66)-derived peptide. J Biol Chem 276:35875-35882

7. Lugardon K, Raffner R, Goumon Y, Corti A, Delmas A, Bulet P, Aunis D, Metz-Boutigue MH (2000) Antibacterial and antifungal activities of vasostatin-1, the $\mathrm{N}$-terminal fragment of chromogranin A. J Biol Chem 275:10745-10753

8. Metz-Boutigue MH, Garcia-Sablone P, Hogue-Angeletti R, Aunis D (1993) Intracellular and extracellular processing of chromogranin A: determination of cleavage sites. Eur J Biochem 217:247-257

9. Helle KB, Corti A, Metz-Boutigue MH, Tota B (2007) The endocrine role for chromogranin A: a prohormone for peptides with regulatory properties. Cell Mol Life Sci 64:2863-2886

10. Mahata SK, O'Connor DT, Mahata M, Yoo SH, Taupenot L, Wu, Gill BM, Parmer RJ (1997) Novel autocrine feedback control of catecholamine release: a discrete chromogranin A fragment is a noncompetitive nicotinic cholinergic antagonist. J Clin Invest 100:1623-1633

11. Mahata SK, Mahata M, Yoo SH, Taupenot L, Wu H, Aroda VR, Livsey CV, Taulane JP, Goodman M, Parmer RJ, O'Connor DT (1998) A novel, catecholamine release-inhibitory peptide from chromogranin A: autocrine control of nicotinic cholinergicstimulated exocytosis. Adv Pharmacol 42:260-264

12. Lee JC, Taylor CV, Gaucher SP, Toneff T, Taupenot L, Yasothornsrikul S, Mahata SK, Sei C, Parmer RJ, Neveu JM, Lane WS, Gibson BW, O'Connor DT, Hook VY (2003) Primary sequence characterization of $\mathrm{Cts}$ intermediates and peptides defines proteolytic cleavage sites utilized for converting chromogranin A into active Cts secreted from neuroendocrine chromaffin cells. Biochemistry 42:6938-6946

13. Helman LJ, Ahn TG, Levine MA, Allison A, Cohen PS, Cooper MJ, Cohn DV, Israel MA (1988) Molecular cloning and primary structure of human chromogranin A (secretory protein I) cDNA. J Biol Chem 263:11559-11563

14. Iacangelo A, Affolter HU, Eiden LE, Herbert E, Grimes M (1986) Bovine chromogranin A sequence and distribution of its messenger RNA in endocrine tissues. Nature 10:82-86

15. Wu HJ, Rozansky DJ, Parmer RJ, Gill BM, O’Connor DT (1991) Structure and function of the chromogranin A gene Clues to evolution and tissue-specific expression. J Biol Chem 15:1313013134

16. Iacangelo A, Okayama H, Eiden LE (1988) Primary structure of rat chromogranin A and distribution of its mRNA. FEBS Lett 227:115-121

17. Sato F, Hasegawa T, Katayama Y, Iwanaga T, Yanaihara N (2000) Molecular cloning of equine chromogranin A and its expression in endocrine and exocrine tissues. J Vet Med Sci 62:953-959

18. Iacangelo AL, Fischer-Colbrie R, Koller KJ, Brownstein MJ, Eiden LE (1988) The sequence of porcine chromogranin A messenger RNA demonstrates chromogranin A can serve as the precursor for the biologically active hormone, pancreastatin. Endocrinology 122:2339-2341

19. Turquier V, Vaudry H, Jégou S, Anouar Y (1999) Frog chromogranin A messenger ribonucleic acid encodes three highly conserved peptides Coordinate regulation of proopiomelanocortin and chromogranin A gene expression in the pars intermedia of the pituitary during background color adaptation. Endocrinology 140:4104-4112

20. Radek KA, Lopez-Garcia B, Hupe M, Niesman IR, Elias PM, Taupenot L, Mahata SK, O'Connor DT, Gallo RL (2008) The neuroendocrine peptide catestatin is a cutaneous antimicrobial and induced in the skin after injury. J Invest Dermatol 128:15251534 
21. Zhang D, Shooshtarizadeh P, Laventie BJ, Colin DA, Chich JF, Vidic J, de Barry J, Chasserot-Golaz S, Delalande F, Van Dorsselaer A, Schneider F, Helle K, Aunis D, Prévost G, MetzBoutigue MH (2009) Two chromogranin a-derived peptides induce calcium entry in human neutrophils by calmodulinregulated calcium independent phospholipase A2. PLoS One 4(2): 4501

22. Breman JG (2001) The ears of the hippopotamus: manifestations, determinants, and estimates of the malaria burden. Am J Trop Med Hyg 64:1-11

23. World Health Organization (2005) http://www.rollbackmalaria. org/wmr2005/

24. Snow RW, Korenromp EL, Gouws E (2004) Pediatric mortality in Africa: Plasmodium falciparum malaria as a cause or risk? Am J Trop Med Hyg 71:16-24

25. Snow RW, Guerra CA, Noor AM, Myint HY, Hay SI (2005) The global distribution of clinical episodes of Plasmodium falciparum malaria. Nature 434:214-217

26. Laufer MK, Plowe CV (2004) Withdrawing antimalarial drugs: impact on parasite resistance and implications for malaria treatment policies. Drug Resist Update 7:279-288

27. Baird JK (2005) Effectiveness of antimalarial drugs. N Engl J Med 352:1565-1577

28. Fidock DA, Rosenthal PJ, Croft SL, Brun R, Nwaka S (2004) Antimalarial drug discovery: efficacy models for compound screening. Nat Rev Drug Discov 3:509-520

29. Biagini GA, O’Neill PM, Nzila A, Ward SA, Bray PG (2003) Antimalarial chemotherapy: young guns or back to the future? Trends Parasitol 19:479-487

30. Go ML (2003) Novel antiplasmodial agents. Med Res Rev 23:456-487

31. Goldberg DE, Slater AF, Cerami A, Henderson GB (1990) Hemoglobin degradation in the malaria parasite Plasmodium falciparum: an ordered process in a unique organelle. Proc Natl Acad Sci USA 87:2931-2935

32. Bjelic S, Nervall M, Gutiérrez-de-Terán H, Ersmark K, Hallberg A, Aqvist J (2007) Computational inhibitor design against malaria plasmepsins. Cell Mol Life Sci 64(17):2285-2305

33. Johansson PO, Chen Y, Belfrage AK, Blackman MJ, Kvarnstrom I, Jansson K, Vrang L, Hamelink E, Hallberg A, Rosenquist A, Samuelsson B (2004) Design and synthesis of potent inhibitors of the malaria aspartyl proteases plasmepsin I and II Use of solidphase synthesis to explore novel statine motifs. J Med Chem 47:3353-3366

34. Liu P, Marzahn MR, Robbins AH, Gutiérrez-de-Terán H, Rodríguez D, McClung SH, Stevens SM Jr, Yowell CA, Dame JB, McKenna R, Dunn BM (2009) Recombinant plasmepsin 1 from the human malaria parasite Plasmodium falciparum: enzymatic characterization, active site inhibitor design, and structural analysis. Biochemistry 48(19):4086-4099

35. Boss C, Richard-Bilstein S, Weller T, Fischli W, Meyer S, Binkert C (2003) Inhibitors of the Plasmodium falciparum parasite aspartic protease plasmepsin II as potential antimalarial agents. Curr Med Chem 10:883-907

36. Jean-Francois F, Khemtemourian L, Odaert B, Castano S, Grelard A, Manigand C, Bathany K, Metz-Boutigue MH, Dufourc EJ (2007) Variability in secondary structure of the antimicrobial peptide Cateslytin in powder, solution, DPC micelles and at the air-water interface. Eur Biophys J 36:1019-1027

37. Trager W, Jensen JB (1997) Continuous culture of Plasmodium falciparum: its impact on malaria research. Int J Parasitol 27:9891006

38. Schuster FL (2002) Cultivation of Plasmodium spp. Clin Microbiol Rev 15:355-364

39. Trager W, Jensen JB (2005) Human malaria parasites in continuous culture. 1976. J Parasitol 91:484-486
40. Lelievre J, Berry A, Benoit-Vical F (2005) An alternative method for Plasmodium culture synchronization. Exp Parasitol 109:195197

41. Kaddouri H, Nakache S, Houze S, Mentre F, Le Bras J (2006) Assessment of the drug susceptibility of Plasmodium falciparum clinical isolates from africa by using a Plasmodium lactate dehydrogenase immunodetection assay and an inhibitory maximum effect model for precise measurement of the 50-percent inhibitory concentration. Antimicrob Agents Chemother 50:3343-3349

42. Benting J, Mattei D, Lingelbach K (1994) Brefeldin A inhibits transport of the glycophorin-binding protein from Plasmodium falciparum into the host erythrocyte. Biochem J 300:821-826

43. Doderer C, Heschung A, Guntz P, Cazenave JP, Hansmann Y, Senegas A, Pfaff AW, Abdelrahman T, Candolfi E (2007) A new ELISA kit which uses a combination of Plasmodium falciparum extract and recombinant Plasmodium vivax antigens as an alternative to IFAT for detection of malaria antibodies. Malar J 6:19

44. Peng J, Schwartz D, Elias JE, T horeen CC, Cheng D, Marsischky G, Roelofs J, Finley D, Gygi SP (2003) A proteomics approach to understanding protein ubiquitination. Nat Biotechnol 21:921-926

45. Elias JE, Gibbons FD, King OD, Roth FP, Gygi SP (2004) Intensity-based protein identification by machine learning from a library of tandem mass spectra. Nat Biotechnol 22:214-219

46. Westling J, Yowell CA, Majer P, Erickson JW, Dame JB, Dunn BM (1997) Plasmodium falciparum, $P$. vivax, and P. malariae: a comparison of the active site properties of plasmepsins cloned and expressed from three different species of the malaria parasite. Exp Parasitol 87:185-193

47. Bonilla JA, Moura PA, Bonilla TD, Yowell CA, Fidock DA, Dame JB (2007) Effects on growth, hemoglobin metabolism and paralogous gene expression resulting from disruption of genes encoding the digestive vacuole plasmepsins of Plasmodium falciparum. Int J Parasitol 37:317-327

48. Jiang S, P rigge ST, Wei L, Gao Y, Hudson TH, Gerena L, Dame JB, Kyle DE (2001) New class of small nonpeptidyl compounds blocks Plasmodium falciparum development in vitro by inhibiting plasmepsins. Antimicrob Agents Chemother 45:2577-2584

49. Zhang D, Shooshtarizadeh P, Laventie BJ, Colin DA, Chich JF Vidic J, de Barry J, Chasserot-Golaz S, Delalande F, Van Dorsselaer A, Schneider F, Helle K, Aunis D, Prévost G, Metz-Boutigue MH (2009) Two chromogranin A-derived peptides induce calcium entry in human neutrophils by calmodulin-regulated calcium independent phospholipase A2. PLoS ONE 4(2): e4501. Published online 2009 Feb 19. doi:10.1371/ journal.pone.0004501

50. Gwadz RW, Kaslow D, Lee JY, Maloy WL, Zasloff M, Miller LH (1989) Effects of magainins and cecropins on the sporogonic development of malaria parasites in mosquitoes. Infect Immun 57(9):2628-2633

51. Shahabuddin M, Fields I, Bulet P, Hoffmann JA, Miller LH (1998) Plasmodium gallinaceum: differential killing of some mosquito stages of the parasite by insect defensin. Exp Parasitol 89(1):103-112

52. Ghosh JK, Shaool D, Guillaud P, Cicéron L, Mazier D, Kustanovich I, Shai Y, Mor A (1997) Selective cytotoxicity of dermaseptin S3 toward intraerythrocytic Plasmodium falciparum and the underlying molecular basis. J Biol Chem 272(50):3160931616

53. Conde R, Zamudio FZ, Rodríguez MH, Possani LD (2000) Scorpine, an anti-malaria and anti-bacterial agent purified from scorpion venom. FEBS Lett 471(2-3):165-168

54. Jaynes JM, Burton CA, Barr SB, Jeffers GW, Julian GR, White KL, Enright FM, Klei TR, Laine RA (1988) In vitro cytocidal effect of novel lytic peptides on Plasmodium falciparum and Trypanosoma cruzi. FASEB J 2(13):2878-2883 
55. Rodriguez MC, Zamudio F, Torres JA, Gonzalez-Ceron L, Possani LD, Rodriguez MH (1995) Effect of a cecropin-like synthetic peptide (Shiva-3) on the sporogonic development of Plasmodium berghei. Exp Parasitol 80(4):596-604

56. Possani LD, Zurita M, Delepierre M, Hernández FH, Rodríguez MH (1998) From noxiustoxin to Shiva-3, a peptide toxic to the sporogonic development of Plasmodium berghei. Toxicon 36(11):1683-1692

57. Ghosh AK, Ribolla PE, Jacobs-Lorena M (2001) Targeting Plasmodium ligands on mosquito salivary glands and midgut with a phage display peptide library. Proc Natl Acad Sci USA 98(23):13278-13281

58. Arrighi RB, Nakamura C, Miyake J, Hurd H, Burgess JG (2002) Design and activity of antimicrobial peptides against sporogonicstage parasites causing murine malarias. Antimicrob Agents Chemother 46(7):2104-2110

59. Mason AJ, Moussaoui W, Abdelrahman T, Boukhari A, Bertani P, Marquette A, Shooshtarizaheh P, Moulay G, Boehm N, Guerold B, Sawers RJ, Kichler A, Metz-Boutigue MH, Candolfi E, Prévost G, Bechinger B (2009) Structural determinants of antimicrobial and antiplasmodial activity and selectivity in histidine-rich amphipathic cationic peptides. J Biol Chem 284(1):119-133

60. Fennell BJ, Naughton JA, Dempsey E, Bell A (2006) Cellular and molecular actions of dinitroaniline and phosphorothioamidate herbicides on Plasmodium falciparum: tubulin as a specific antimalarial target. Mol Biochem Parasitol 145:226-238

61. Kappes B, Rohrbach P (2007) Microtubule inhibitors as a potential treatment for malaria. Future Microbiol 2:409-423

62. Gupta A, Mehra P, Dhar SK (2008) Plasmodium falciparum origin recognition complex subunit 5: functional characterization and role in DNA replication foci formation. Mol Microbiol 69:646-665

63. Ersmark K, Nervall M, Gutierrez-de-Teran H, Hamelink E, Clemente Janka LK, JC Dunn BM, Gogoll A, Samuelsson B, Qvist J, Hallberg A (2006) Macrocyclic inhibitors of the malarial aspartic proteases plasmepsin I, II, and IV. Bioorg Med Chem 14:2197-2208

64. Ersmark K, Samuelsson B, Hallberg A (2006) Plasmepsins as potential targets for new antimalarial therapy. Med Res Rev 26:626-666

65. Bonilla JA, Bonilla TD, Yowell CA, Fujioka H, Dame JB (2007) Critical roles for the digestive vacuole plasmepsins of Plasmodium falciparum in vacuolar function. Mol Microbiol 65:64-75

66. Ersmark K, Nervall M, Hamelink E, Janka LK, Clemente JC, Dunn BM, Blackman MJ, Samuelsson B, Aqvist J, Hallberg A (2005) Synthesis of malarial plasmepsin inhibitors and prediction of binding modes by molecular dynamics simulations. J Med Chem 48:6090-6106 